\title{
The Integration of Reclaimed Materials in Landscape Design
}

\author{
Yu-Han Shao \\ Landscape Department, College of Architecture and \\ Urban Planning, Tongji University \\ Shanghai, 200092, China \\ Email: shaoyuhan7@hotmail.com
}

\begin{abstract}
This research attempts to study recycled and reclaimed materials to explore how they are used in landscape designs. The major kinds of recycled materials are analyzed such as plastics, crushed glass, steel, timbers, concrete and tires. Hence, the research produces an analysis of different materials used in the urban space. The methodology was proven via case study of onsite observation at the BRE Innovation Park in London.
\end{abstract}

Keywords-reclaimed materials; recycled materials; landscape design.

\section{INTRODUCTION}

From the emergence of global warming and environmental pollution, human beings are starting to think about how to reduce the overload of the global energy. People are starting to consider this problem to see if it is not too late. Such researches are proven to be worthwhile and valuable. Landscape architects are now beginning to consider environmental works; some of them are focusing on ecological design. Recycled and reclaimed materials are being used very often in landscape design. Besides, the western government has also adopted a series of facilities to help the environment starting with recycling waste materials.

\section{RECYCLED And RECLAIMED MATERIALS}

Reusing waste materials means reduce pollution and promote environmental quality. The benefits of re-using waste include: good for the environment keeps waste out of landfill and have important financial benefits for both businesses and households. Collins and Sherwood said, "If waste materials are to be used they must satisfy the test requirements that are imposed on naturally occurring aggregates used for the same purpose" [1]. Some materials are in a circulation stock from one sharp to another that the circulating stock decreases when the energy of the material is unavoidably lost. In the process of reusing human being should pay attention of saving energy and suitable reusing and recreate those waste materials [2].

There are mass of reclaimed materials used in modern landscape design such as reclaimed brick, stone and timber. Some designers who love nature like using recycled local stones combine them with other reclaimed materials such as tiles, paddle stones and reclaimed bricks together in the design. Anderson \& Howard [3] mentioned that there is a condition to use reclaimed material, short transported distances is important which reclaimed materials are more sustainable [4]. Use of reclaimed bricks and lime mortar to

\author{
Bin-Yi Liu \\ Landscape Department, College of Architecture and \\ Urban Planning, Tongji University \\ Shanghai, 200092, China
}

build dry stonewall in which the activity is excellent habitat for insects and other wild creatures. Reclaimed wood, including oak and other hardwoods are available. Compare with all above materials, Woolley and Kimmins had a conclusion: recycled materials are probably one of the best options for fencing [5]. Reclamation of materials reduces pressure on virgin resources, has low manufacturing impact, low energy input and avoided pollution.

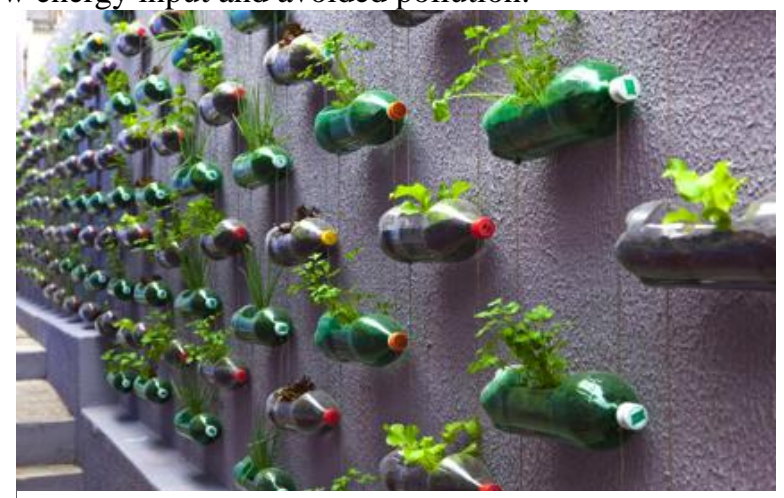

Figure.1. Recycled plastics

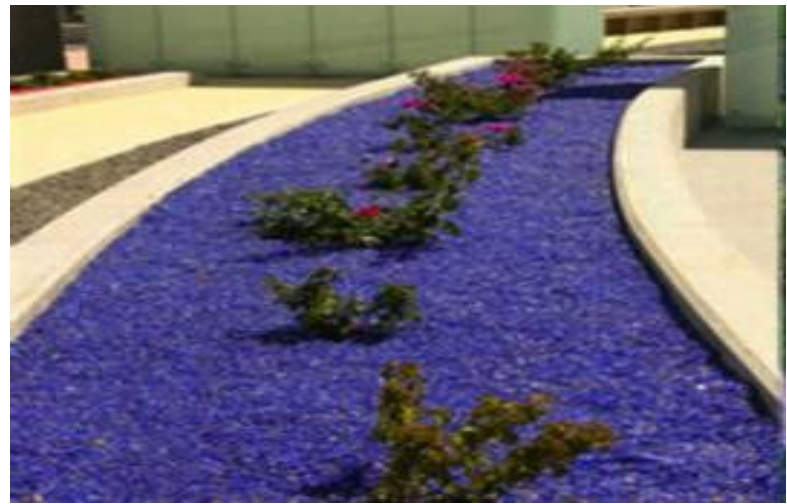

Figure.2. Recycled crushed glasses 


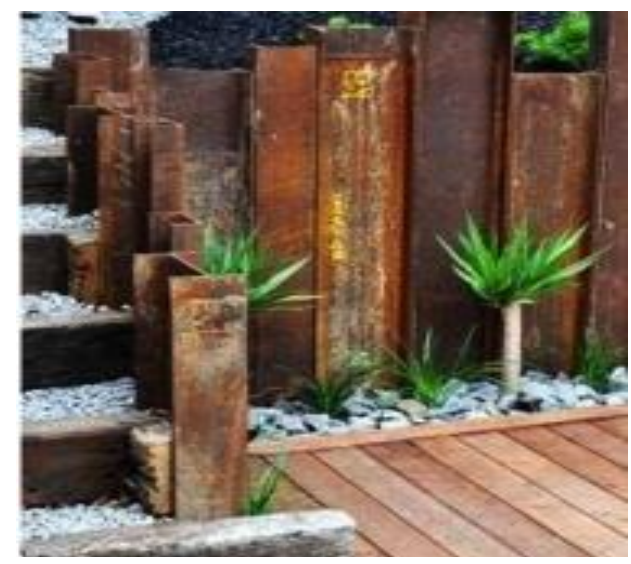

Figure.3. Recvcled Steels

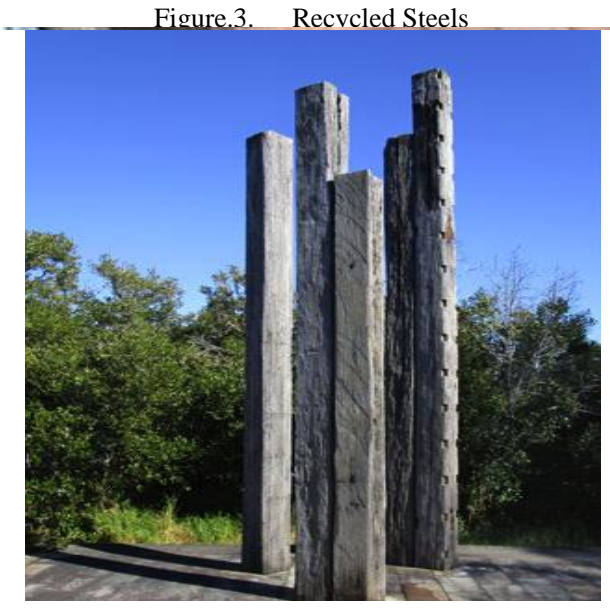

Figure.4. Recycled timber

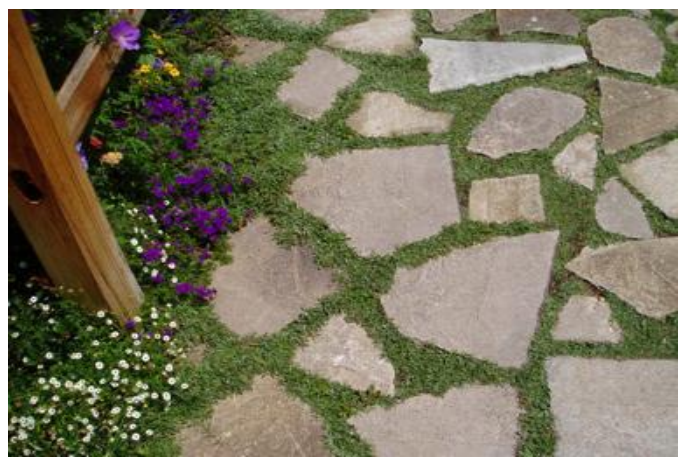

Figure.5. Reclaimed concrete

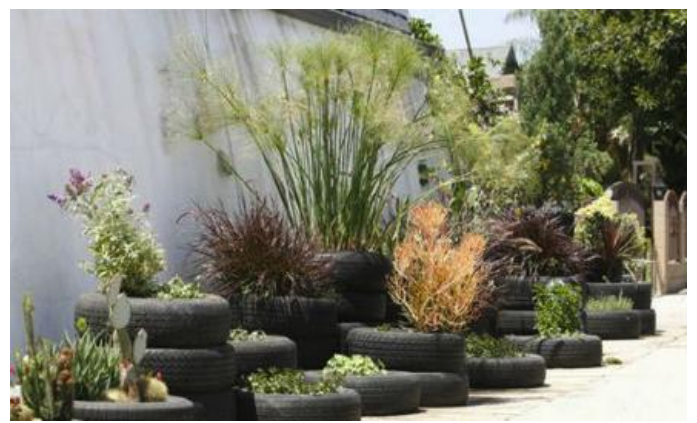

Figure.6. Recycled tires

\section{A. Recycled Plastic}

Recycled plastic is better than timber or metal, especially when considering the cost of maintenance, both financially and environmentally. It transforms rubbish into a high quality product (as shown in Figure.1). Wasteonline.org showed that recycled plastics can recreate the products flooring and window frames; PVC sewer pipe; building insulation board; fencing and garden furniture, water butts, garden sheds and composters [6]. Plastic have a wild scale use in the recycled market [7]. An example from Smile Plastics Company which is the home of recycled plastics, they used mobile cases to create a main idea of board, the company investigate that there is about 45 million mobiles in the UK every year 15 million of them are disposed, some are refurbished and sold again, however, most of them are scraped and landfilled which is add burden of the earth and the environment [8]. As a result, few benefits from plastic recycling are summarised: Less plastic waste going to landfill; Less oil used for plastic production; Less energy consumed.

However, Woolley and Kimmins reported that many of recycled materials contain potentially harmful chemicals [5]; it is impact on human health and the environment, such an example is phthalates, which are used in the manufacture of PVC [3]. Berge also pointed out that gas emitted when PVC burnt [9]. Fortunately, Thompson \& Sorvig claimed HDPE or other plastics could replace PVC [10].

\section{B. Recycled Crushed Glass}

Glass is one of the easiest materials to recycle; however, glass is an energy-intensive process when re-melting [11]. Crushed glass is one of the most versatile of all recycled materials in landscape which functional resemblance to sand and more decorative purpose (shown in Figure. 2), but here should be noted that the glass for all functional uses should be tumbled to smooth away sharp edges [10]. About the versatile uses of recycled crushed glass, it is classified in to three areas: "as a replacement for sandin concrete, asphalt, and other paving; as a fill material to replace aggregate; and as an in gradient in tiles and similar products." [10]. The function as an in gradient in tiles and similar products, Thompson and Sorvig explained it by using examples such as Stoneware Tile Company (Richmond IN) use minimum $70 \%$ of glass to the manufactures colourful pavers [10]. Recycle glass tile contains abundant ornaments, this function decide they are commonly used in garden landscapes. Glass block is available from recycled glass in standard sharp and size. Also in modern landscape design, glass has been used successfully in the construction of bike path, pedestrian, parking areas and so on.

\section{Recycled Steel}

There is scope for steel to be produced sustainably as people thought to increase the extent of recycling and using renewable energy [5]. Tones of recycled steel are from recycled cans, appliances, automobiles, and construction materials. This is re-melted to produce new steel. SCRIB investigate that 4 billion steel cans were recycled in the UK in 2007 which equivalent to each household in the UK 
recycled 70\%of the steel consumption [12]. SCRIB reported $100 \%$ steel packaging can be recycled and without any loss of quality [13]. The benefit for recycling steel is helping preserve natural resources and promote the environment; save it from going into landfill sites; help the UK to reach its target of recycling 54\% of steel packaging by 2008 . From SCRIB showed that every tonne of steel packaging recycled makes environmental savings: 1.5 tonnes of iron ore; 0.5 tonnes of coal; $40 \%$ of the water required in production; $75 \%$ of the energy needed to make steel from virgin material; 1.28 tonnes of solid waste; Reduction of air emission by $86 \%$; Reduction of CO2 emissions by $80 \%$; Reduction of water pollution by $76 \%$ [13].

In modern landscape design, steel is used a lot (as shown in Figure.3). Designers like the rusty colour of steel that means history. Recycled steel is recreated to new metals and reused again. However, compare to raw steel, stainless steel is more sustainable than mild steels, with low maintenance and high recyclable [5].

\section{Recycled Timber}

Renewable materials such as reused wood have played a great role in energy generation, engineered construction solutions, construction, and other products' manufacturing [14]. "Recycled Timber is salvaged from Demolished Houses, Old Buildings, Sheds Factories, Warehouses, Wharves, Boats, etc." It has minimal environmental impact and significantly reduces waste and energy expenditure [15]. Obviously, use recycled wood from doors, windows and structural timber is beneficial compare to new wood, because of saving energy and resources. Brighton\& Hove Wood Recycling Project shows a serious of recycled timbers products used in landscape such as in Figure. 4 [16]. Berge mentioned that water could affect timber's durability; normally the timber exposed to water is living longer than hide in sheltered place because lower amount of oxygen, timer in swamps can live thousands of years [9].

\section{E. Reclaimed Concrete}

There is a large number of concrete as buildings' foundations, ceilings, floors, walls, and seats have been produced [9]. Portland cement-based concrete can also be recycled in European countries (shown in Figure.5). It is used for casting of concrete slabs for basement of houses and parking areas. But reclaimed concrete is not solid enough. Based on that, concrete normally reinforced by using steels recycled from scrap metal, but always add $10 \%$ new steel inside to improve the strength. According to the different situation of areas, the first choice must be local materials, because it is convenience and save energy. Above all, obviously, reclaimed concrete is used a lot but most of them used in architecture and social facilities, in the landscape aspects, reclaimed concrete is used in pavement and some other functions. Here one point should be attention that reclaimed concrete should work with steel together to reinforce itself which is consider about people's health and product quality.

\section{F. Recycled Tires}

Worn-out rubber tires from cars are a familiar decorative element in the vernacular landscape (shown in Figure.6). "Rubble tires are being put functional uses in landscape, such as stream-bank and slope stabilization; for construction check-dam; as a surfacing material; for marine construction; and as an ingredient in rubberized asphalt." [10]

Hall pointed out that to reduce environmental impact, one needs to consider more sustainable alternatives to gravel including recycled glass chips which include ranges of colors, also consider organic materials, such as bark chips or shells [4]. Old tires or other discarded items can be used as experimental bed edgings in garden [4]. The constructional techniques have been developed to deal directly with some of the waste arising from industry. One of the most enduring has been the common tire. Rammed full of earth and tied together, these are commonly seen in the US; Benefit from the re-use of waste, the design is more ecological.

\section{CASE STUDY: BRE INNOVATION PARK IN} LONDON

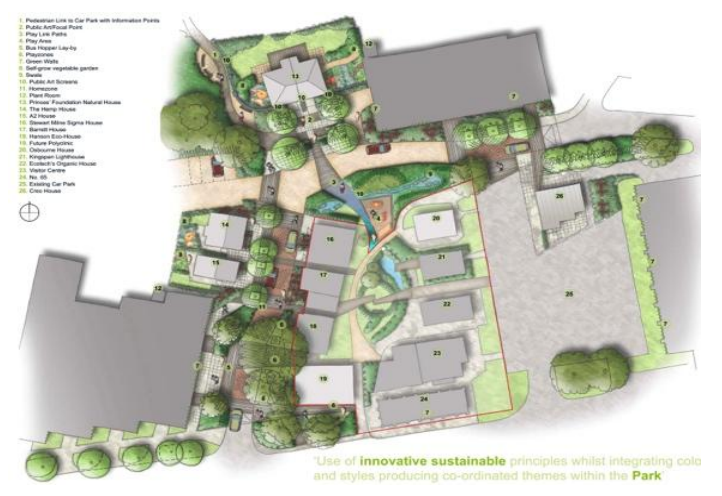

Figure.7. BRE innovation park

BRE Innovation Park is an ambitious landscape to complement the innovation in building technology project (Figure.7). The site is located at Watford UK, the objectives for PRP creating Innovation Park are: reducing of carbon emissions and suppressing climate change; to integrate of SuDS, which reduce of energy costs; using of recycled resources in the site; ecological planting strategies; a placement sense of the site. The park looks different for a number of reasons: the site is not only quite smaller and congested, but also has a large forest behind the site, which presents different challenges; there has a road going in front of the site, it is an opportunity to create home zone or find a way of creating or treating a shared surface. It is giving an opportunity for landscape architects to show that is only way to good quality landscape architecture, which could meet code level 5 or 6 of carrying sustainable home. It is attempted to improve the significance of good quality sustainable landscape in the content of house development.

\section{SITE OBSERVATION}

There is $90 \%$ of landscape hard surface paving materials are permeable. The paved surfaces are from recycled or sustainable sources. After visited the site, the author find the 
permeable pavements are used significantly, some of the paving are from recycled materials. Such as recycled granite/nitrogen dioxide fixing pavers; recycled glass/sand and aggregates; exposed aggregate concrete; eco-granite (77\% of the eco-granite are from recycled materials).

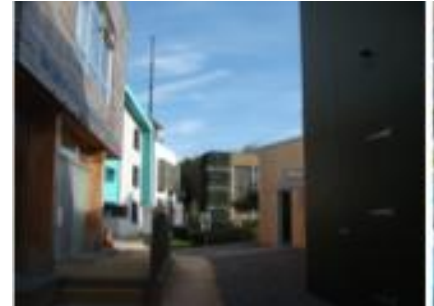

Figure.8

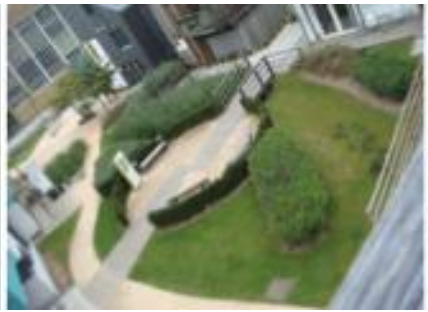

Figure. 9

From the entrance to the BRE Innovation Park center, Nidagravel® (gravel stabilisation system) and Traxmax (100\% recycled ceramic aggregate shows on photo 1) are used. Those materials can combine with SUDS very well. The main landscape area contains community center, children's natural play area (shown in Figure.8). Figure.9

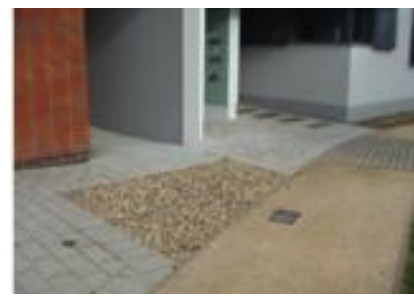

Figure.12

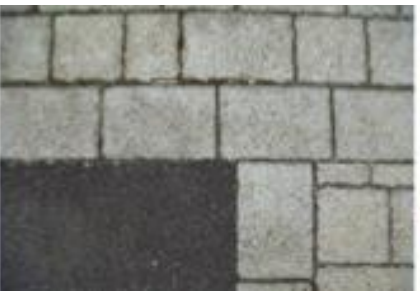

Figure.13

The recycled sand surface, which shows in Figure.12 and eco-granite (Figure 13) are used on the site. The ecogranite could infiltrate runoff water to basin. Additionally, the vegetation area's topsoil is a by-product from British sugar-soil washed from sugar beet is collected and sold (Figure.13). The landscape designer sets three seats which

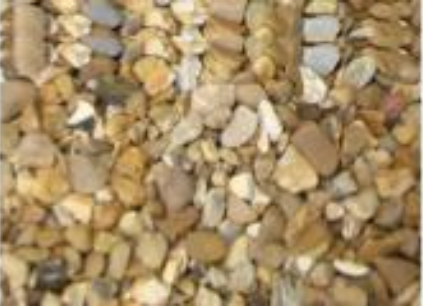

Figure.10

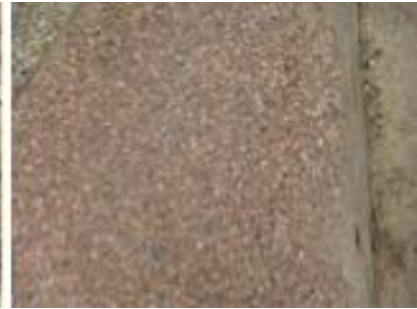

Figure.11

show the birds' eyes views to the BRE Innovation Park landscape; many materials construct the pavements. The old oak timber decking is from local site. The pavements also include CEDECTM Gold footpath gravel (Figure.10); exposed aggregate concrete (Figure. 11).

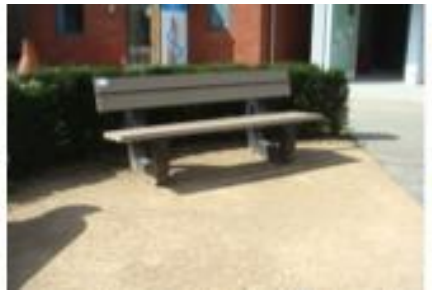

Figure.14

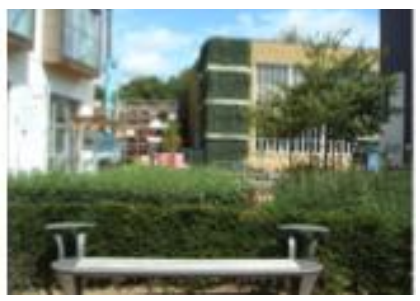

Figure.15

are recycled from plastic as in Figure. 14 and 15. The materials of the chairs look like timbers, steels, but the texture is plastic. The decking and seating were to be constructed from recycled timber by Rick Levene in partnership with London Recycled Timber.

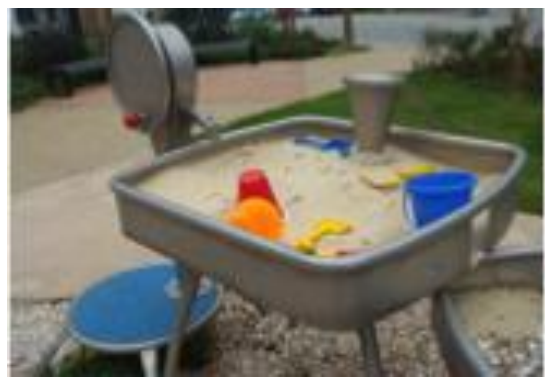

Figure.16

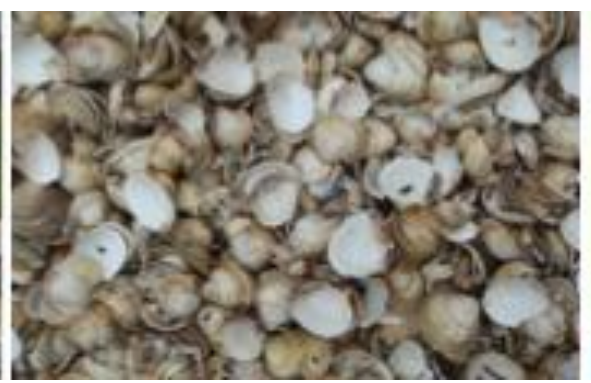

Figure.17

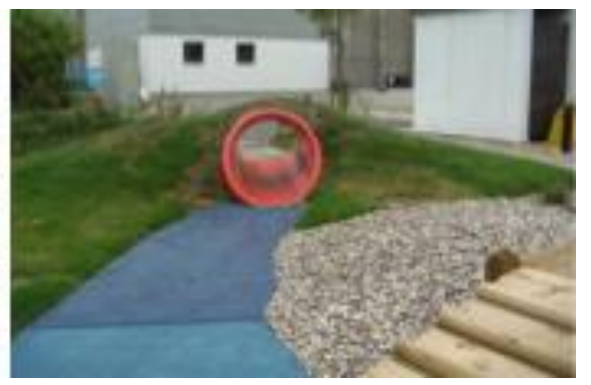

Figure.18
In the children's playground, the materials are different from the community center. The designer mixes using of sands and recycled shells in the containers for children playing. Figure. 16 and 17 shows the texture of the materials. The different colors of concretes are used in the playground (Figure. 18).

To sum up, the BRE Innovation Park is a good example of modern sustainable design. The reused and sustainable resources are combined successfully in the whole system. The most successful of this sustainable project are the designers in the site are always very innovating to explore new techniques to help the sustainable landscape to reach new levels.

\section{DISCUSSION}

The recycled materials are used differently depend on 
the function of the site. The literature review part was mentioned the recycled materials functions but not for the specific areas. For the BRE Innovation Park, they used the paving for vehicles passing, the materials such as Aquaflow ${ }^{\circledR}$ permeable block paving is for collecting and filtering water for later use, but it is not made from recycled material. For the soft landscape pavement, the park does not use Aquaflow ${ }^{\circledR}$ permeable block paving, they use recycled gravels, recycled sand and so on for paths and vegetation topsoil. Such landscape also helps local buildings to achieve sustainable code levels. The commonly used recycled materials in landscape are recycled plastic for benches, recycled hogging and slab pavement surfaces which are good for water's filtration. For the vegetation area, they used massive recycled topsoil for vegetation growing such as from wasted vegetation and fruit market and so on.

Recycled materials can attract people to visit the site because it is sustainable and special. Recycled materials also have educational functions. Based on the literature reviews and case studies, the energy cost of the recycled and reused materials is proven to be less than normal materials. Such as the concrete should be avoided to be used which is energy inefficient. The local materials are also quite sustainable; the reason is that local materials do not need long distance transportation; it can reduce the $\mathrm{CO} 2$ emission from the car, which is good for environment. However, the budget of sustainable design is more expensive than normal project. The BRE Innovation Park is more expensive than usual projects. But in the literature review part, Barton states that the sustainable development should meet the balance among the environmental, economic and social needs [17]. But in those two case studies, they are both quite expensive. For the individual project, it can save the electronic costs and is good for the environment. Nowadays, the governments have paid sizable finances to recover the environments, to avoid this situation; it deserves costing high price in the sustainable project before harming the environment.

\section{CONCLUSION}

Landscape should be thought as a system not just a form of the site but also the functions, energies, reuses, ecology of the site. The recycled and reclaimed materials can be combined together in landscape projects. Those ecological designs recreate and promote the resource reusing and which is good for the environment. The case studies show the commonly used recycled materials in the landscape project such as recycled timbers, recycled plastics, recycled stones etc., the sustainable play the main lead of the landscape design. Based on the research, landscape architects play a role to protect the environment, especially when they start using materials in design. The using of recycled and reclaimed materials should be advocated. The recycled materials are not used very often in landscape design because lots of landscape architects still like using new materials in their designs. Additionally, parts of people have resistance to recycled materials; some families do not even have the awareness of environmental protection.

Hence, landscape architects should focus on sustainable design in future projects, which are for the environmental consideration. To think about the input, output links to the project, the landscape architects should consider the water, air, energy, food and drink, people, plants, vehicles/other materials. The secondary consideration is the technical, environmental, social and economic. The landscape designers could encourage the clients to use of storm water and grey water, to limit the potable water in the projects. The landscape companies could work with some sustainable material organizations such as WRAP to achieve the low energy costs projects. Meanwhile, the government could encourage increasing the environmental awareness. The governments could encourage the sustainable landscape projects created not just in the research place but also in the city centers or some public space. It will be more convenient for people to learn the concept of sustainability and add environmental awareness. The educational effect can raise the public awareness of environmental issues through media, courses for students and training programs for residents.

\section{REFERENCES}

[1] Collins R.J. and Sherwood P.T., Use of waste and recycled materials as aggregates: standards and specifications: a report prepared by the Building Research Establishment (BRE) for the Department of the Environment, London, HMSO, 1995.

[2] Frosch, R.A. and Gallopoulos N., Strategies for manufacturing. Scientific American, 1989, 261(3): 144-152

[3] Anderson, J. and Howard, N., The green guide to housing specification: an environmental profiling system for building materials and components, London, Construction Research Communications, 2000.

[4] Hall, K., The green building bible. Vol.1 (3rd ed). Llandysul, Green Building, 2006.

[5] Woolley, T. and Kimmins, S., Green building handbook: a guide to building products and their impact on the environment, vol.2. London, E \& FN Spon, 2000.

[6] Wasteonline.org, Plastics recycling information sheet, 2006, http://www.wasteonline.org.uk/resources/InformationSheets/Plastics. htm.

[7] Smile Plastics, Garden design at RHS Tatton, 2008, http://www.smile-plastics.co.uk/showItemPicture.asp?pid=58.

[8] British plastics federation, Plastic recycling, 2003, http://www.bpf.co.uk/bpfindustry/Plastics_Recycling.cfm.

[9] Berge, B., The ecology of building materials. Oxford, ButterworthHeinemann, 2000.

[10] Thompson, J. W. and Sorvig, K., Sustainable landscape construction: a guide to green building outdoors. Washington, D.C. Island, 2000.

[11] Addis, W., Building with reclaimed components and materials: a design handbook for reuse and recycling. London, Sterling, VA: Earthscan, 2006.

[12] SCRIB, Recycling steel, 2008, http://www.scrib.org/recycling_steel/recycling_steel.asp.

[13] SCRIB, Recycling steel, http://www.scrib.org/recycling_steel/why_recycle_steel.asp.

[14] Bre., Timber and sustainability, http://www.bre.co.uk/page.jsp?id=900.

[15] The RIC Good Wood Guide, Recycled Timber - the Number One Choice, http://www.rainforestinfo.org.au/good_wood/recyc_t.htm.

[16] Brighton \& Hove, 2008,Wood Recycling Project. http://www.woodrecycling.org.uk/sale_product.html. 
[17] Barton, H., Conflicting perceptions of neighbourhood. In: Sustainable Communities: The Potential for Eco-Neighbourhoods. H. Barton (Ed.)
London: Earthscan, 2000. 